\title{
Pectinmethylesterase extraction from orange solid wastes: Optimization and comparison between conventional and ultrasound-assisted treatments
}

\author{
Antonio D. Rodriguez-Lopez ${ }^{1^{*}}$, Luis Mayor², María M. Galfarsoro², Jorge Martinez-Otalo², \\ Esperanza M. Garcia-Castello ${ }^{2^{\star}}$ \\ ${ }^{1}$ Department of Chemical and Nuclear Engineering, Universitat Politècnica de València, Camino de Vera, s/n. CP 46022, Valencia, \\ Spain; *Corresponding Author: anrodlo@iqn.upv.es \\ ${ }^{2}$ Institute of Food Engineering for Development, Universitat Politècnica de València, Camino de Vera, s/n. CP 46022, Valencia, \\ Spain; ${ }^{*}$ Corresponding Author: egarcia1@iqn.upv.es
}

Received August 2013

\begin{abstract}
During orange juice production, a half of fresh oranges weight is considered as production waste (peels, pulp, seeds, orange leaves and damaged orange fruits). An alternative for the management of these wastes is their treatment by addition of lime and a latter pressing, obtaining a press cake and a press liquor rich in sugars $\left(10^{\circ} \mathrm{Brix}\right)$ and citric acid, protein, pectin and ethanol. For non-thermal concentration of press liquor to obtain citruss molasses $\left(65^{\circ}-70^{\circ}\right.$ Brix), the removal of pectin is necessary. Traditionally, depectinization of juices has been done by using pectinmethylesterase (PME) enzymes from external sources. In this work it performed the extraction of PME enzymes from orange peels to obtain the optimum extraction conditions. Two different methods of solvent extraction were compared (conventional and ultrasound-assisted methods). For the conventional extraction experiments, a central composite design with three variables ([NaCl], $\mathrm{pH}$ and time) and five replicates of the center point was used. For ultrasound-assisted extraction, experiments were done at $\mathrm{pH}=5.5$ and $[\mathrm{NaCl}]=1.25 \mathrm{M}$ ), varying extraction time (1 - $30 \mathrm{~min})$. Response variables were PME activity, protein content and a ratio between them, named PME effectiveness $\left(\eta_{\mathrm{PME}}\right)$. At the same experimental conditions ( $\mathrm{pH}$ $=5.5,[\mathrm{NaCl}]=1.25 \mathrm{M}, \mathrm{t}=15 \mathrm{~min}$ ) it was found that conventional extractions led to slightly better results in terms of $\eta_{\mathrm{PME}}$ than ultrasound-assisted extraction method.
\end{abstract}

Keywords: Orange Peel; Solid-Liquid Extraction;
Ultrasound-Assisted Extraction;

Pectinmethylesterase; Press Liquor

\section{INTRODUCTION}

During orange juice production only approximately the half of fresh oranges weight is transformed into juice [1] while the other half is considered as production waste (peels, pulp, seeds, orange leaves and damaged orange fruits) [2]. The United States Department of Agriculture (USDA) forecasted a world production of orange juice of $2.2 \times 10^{6}$ metric tons (MT) [3] in 2010, which would lead to around $1.1 \times 10^{6} \mathrm{MT}$ of solid wastes.

These wastes are, in most cases, spread on soil areas adjacent to the production locations, for a final use as raw material for cattle feed, or burned [4]. This way of waste handling produces highly polluted wastewater in terms of chemical and biological oxygen values (COD and BOD) [1] that can negatively affect the soil the ground and superficial water.

The most desirable procedure under both environmental and economical points of view is the selection of waste treatment alternatives directed to their integrated valorization. An alternative to improve the management of orange solid wastes is their treatment by addition of lime and a latter pressing, obtaining a press cake and press liquor rich in sugars (sucrose, glucose and fructose) with a total concentration of around $10^{\circ}$ Brix. Other components present in the press liquor are citric acid, protein, pectin and ethanol [1].

Currently, the orange press liquor is concentrated up to $65^{\circ}-70^{\circ}$ Brix by multiple effect evaporation to obtain molasses that are used in the production of beverage alcohol [5], and as cattle feed [6]. The evaporative concentration implies very high energy consumptions when compared with non-thermal membrane operations, as reported 
in the preconcentration of sucrose solutions by reverse osmosis (RO) [7].

Some attempts of press liquor preconcentration by RO and forward osmosis (FO) have been done. In the RO preconcentration it was found that the presence of pectin in synthetic press liquor made its treatment very difficult mainly due to the high viscosity of the solution whilst when the press liquor was prepared without pectin, the solution was satisfactorily preconcentrated for all tested conditions [8]. In the case of the FO treatment, it was found that synthetic press liquor solution prepared without pectin could be concentrated up to 2.5 folds the press liquor prepared with pectin [9]. Hence, a depectinization step is strongly recommended for membrane concentration of press liquor.

Pectin is a heteropolysaccharide that consists of long sequences of partially methyl-esterified d-galacturonate residues interrupted by other sugars such as d-xylose, dglucose, l-rhamnose, l-arabinose and d-galactose [10].

There are many studies of juice depectinization to obtain clarified products by using commercial enzymes such as pectinmethylesterase (PME) (EC 3.1.1.11) or polygalacturonase (EC 3.2.1.15) [11]. PME enzymes are naturally present in the peel of several fruits such as oranges and apples $[1,10,12]$. Based on results obtained by Garcia-Castello et al. [8] and Garcia-Castello and McCutcheon [9] with synthetic press liquor solutions it would be expected a considerable improvement in the preconcentration yield of press liquor by membrane technology.

In this work it performed the extraction of PME enzymes from orange peels to obtain the optimum extraction conditions. Two different methods of solvent extraction were compared (conventional and ultrasound-assisted extraction).

\section{MATERIALS AND METHODS}

\subsection{Raw Materials}

"Valencia Late" (Citrus sinensis L.) oranges were purchased from a local market in Valencia, Spain. Oranges were carefully washed with tap water and stored at $5^{\circ} \mathrm{C}$ until use. Fruits were cut into halves and the juice was extracted using a domestic squeezer (Philips, Royal Philips Electronics, Inc., The Netherlands). The remaining peels were used for the conventional and ultrasoundassisted extraction of PME.

\subsection{Extraction of Pectinmethylesterase Enzymes. Experimental Design}

Two different methods of solvent extraction were compared: conventional and ultrasound-assisted extraction. For the conventional extraction experiments, a central composite design (CCD) with three variables ( $\mathrm{NaCl}$ concentration, $\mathrm{pH}$ and time) and five replicates of the center point was used. Real and coded values for each variable are listed in Table 1. For ultrasound-assisted extraction, some of the experiments shown in Table 1 were selected, namely those of the center point $(\mathrm{pH}=5.5,[\mathrm{NaCl}]=$ $1.25 \mathrm{M}$ ), but in this case tested times were 1, 5, 15, 25 and $30 \mathrm{~min}$. Response variables in every experiment for both extraction methods were PME activity and protein content in extracts.

Independently of the method used the extraction was done as follows: a 25 g sample of orange peels (natural or pressed) was suspended into $100 \mathrm{~mL}$ of extracting aqueous solution at different $[\mathrm{NaCl}]$. The mixture was homogenized in an electrical blender (Turbomix plus 300, Moulinex, France). The pH of the homogenate was adjusted to different values according to the experimental design using small volumes of concentrated $\mathrm{NaOH}$ and $\mathrm{HCl}$ solutions. In the conventional extraction experiments, homogenates were stirred in an orbital shaker at $175 \mathrm{rpm}$ and at constant temperature of $4^{\circ} \mathrm{C}$ for the time established in Table 1. In the ultrasound-assisted extraction experiments, homogenates at $\mathrm{pH} 5.5$ and with a $[\mathrm{NaCl}]$ of 1.25 $\mathrm{M}$ were introduced in flasks and then in an ultrasound device (ATM-7,0LCD, Labbox; frequency, $40 \pm 2$ $\mathrm{kHz}$ ) at a constant temperature of $4^{\circ} \mathrm{C}$ for the times commented previously in this section.

Afterwards, samples were vacuum filtered. The crude extract was centrifuged at 13,000 rpm for 30 minutes at $4^{\circ} \mathrm{C}$ (Medifriger BL-S, JP Selecta, S.A., Spain). The supernatants (enzymatic extract) were kept at $-20^{\circ} \mathrm{C}$ until analysis.

Table 1. Natural and coded (in brackets) variables for the experimental factors $\mathrm{pH}, \mathrm{NaCl}$ concentration and time in the central composite design for conventional extraction of PME enzyme from orange peel wastes.

\begin{tabular}{cccc}
\hline Run & $\mathrm{pH}\left(\mathrm{X}_{1}\right)$ & {$[\mathrm{NaCl}](\mathrm{M})\left(\mathrm{X}_{2}\right)$} & Time $(\mathrm{min})\left(\mathrm{X}_{3}\right)$ \\
\hline 1 & $7.0(+1.0)$ & $0.5(-1.0)$ & $40(-1.0)$ \\
2 & $5.5(0.0)$ & $1.25(0.0)$ & $20(-1.682)$ \\
3 & $8.0(+1.682)$ & $1.25(0.0)$ & $70(0.0)$ \\
4 & $7.0(+1.0)$ & $0.5(-1.0)$ & $100(+1.0)$ \\
5 & $4.0(-1.0)$ & $0.5(-1.0)$ & $40(-1.0)$ \\
6 & $5.5(0.0)$ & $1.25(0.0)$ & $70(0.0)$ \\
7 & $5.5(0.0)$ & $1.25(0.0)$ & $70(0.0)$ \\
8 & $7.0(+1.0)$ & $2.0(+1.0)$ & $40(-1.0)$ \\
9 & $7.0(+1.0)$ & $2.0(+1.0)$ & $100(+1.0)$ \\
10 & $5.5(0.0)$ & $1.25(0.0)$ & $121(+1.682)$ \\
11 & $5.5(0.0)$ & $1.25(0.0)$ & $70(0.0)$ \\
12 & $5.5(0.0)$ & $2.5(+1.682)$ & $70(0.0)$ \\
13 & $5.5(0.0)$ & $1.25(0.0)$ & $70(0.0)$ \\
14 & $4.0(-1.0)$ & $0.5(-1.0)$ & $100(+1.0)$ \\
15 & $5.5(0.0)$ & $1.25(0.0)$ & $70(0.0)$ \\
16 & $4.0(-1.0)$ & $2.0(+1.0)$ & $100(+1.0)$ \\
17 & $5.5(0.0)$ & $0.0(-1.682)$ & $70(0.0)$ \\
18 & $4.0(-1.0)$ & $2.0(+1.0)$ & $40(-1.0)$ \\
19 & $3.0(-1.682)$ & $1.25(0.0)$ & $70(0.0)$ \\
\hline
\end{tabular}




\subsection{Analytical Determinations}

\subsubsection{Pectinmethylesterase Activity}

The PME activity of the extracts was determined as described by several authors [13-18]. This method measures the releasing rate of carboxylic groups from a $1 \%$ $(\mathrm{w} / \mathrm{v})$ standard citrus pectin (Sigma) solution at $30^{\circ} \mathrm{C}$ and $\mathrm{pH} 7$ when the enzymatic extract is added. A volume of $20 \mathrm{~mL}$ of the $1 \%$ pectin solution was adjusted to $\mathrm{pH} 7$ keeping the temperature constant at $30^{\circ} \mathrm{C} .4 .75 \mathrm{~mL}$ of the enzymatic extract were added and as soon as the $\mathrm{pH}$ decreased due to the release of carboxylic groups, the $\mathrm{pH}$ was re-adjusted to a value of 7 using a solution of $0.01 \mathrm{M}$ $\mathrm{NaOH}$. This $\mathrm{pH}$ re-adjustment was made as often as necessary during 10 minutes. One unit of PME activity was defined as 1 eequivalent of carboxyl groups released per minute and millilitre of enzymatic extract $(\mathrm{U} / \mathrm{mL})$. PME activity units were given in $\mathrm{U}$ per $\mathrm{mg}$ of orange peel in dry basis (U/mg (d.b.).

\subsubsection{Protein Content}

The protein content determination was done according to the Bradford method [19]. This method is based on a colorimetric determination of the presence of proteins at a wavelength of $595 \mathrm{~nm}$. The protocol was the following: $3 \mathrm{~mL}$ of the Bradford reagent (Sigma Aldrich Co., St. Louis, MO, USA) were added to $300 \mu \mathrm{L}$ of sample, and after $30 \mathrm{~min}$. the absorbance was measured in a UV/ Visible spectrophotometer (Ultrospec 3300pro; Amersham Bioscience, Piscataway, NJ, USA). A calibration curve was done using standard bovine serum albumin (Sigma Aldrich Co., St. Louis, MO, USA) solutions. Protein content was given in $\mathrm{mg}$ of protein per $\mathrm{mg}$ of orange peel in dry basis (mg prot/mg (d.b.).

\subsubsection{Moisture Content in Orange Peels}

Five orange fruits were cut and squeezed as described before. Peels were cut by hand in pieces of similar size and then were weighted. Afterwards, samples were introduced in a vacuum oven at $60^{\circ} \mathrm{C}$ and -0.60 bar (Vacioterm, JP Selecta, S.A., Spain) until constant weight. Moisture content was determined from weight difference before and after sample drying.

\subsection{Statistical Analysis}

All the analyses were conducted in triplicate. Data was expressed as the average of these values. The results of the CCD were analyzed using the software "Statgraphics" version Centurion XVI, from StatPoint Technologies, Inc, USA. Linear and quadratic effects of the three variables considered, as well as their interactions on the response variables were calculated. Their significance was evaluated by analysis of variance (ANOVA).

Moreover, experimental data were fitted to a second- order polynomial model (Eq.1) and regression coefficients were obtained $\left(\mathrm{R}^{2}\right)$.

$$
\begin{aligned}
Y= & \beta_{0}+\beta_{1} X_{1}+\beta_{2} X_{2}+\beta_{3} X_{3}+\beta_{4} X_{1}^{2}+\beta_{5} X_{2}^{2} \\
& +\beta_{6} X_{3}^{2}+\beta_{7} X_{1} X_{2}+\beta_{8} X_{1} X_{3}+\beta_{9} X_{2} X_{3}
\end{aligned}
$$

where $Y$ is the studied response, $\beta_{0}$ is the independent coefficient, $\beta_{1}, \beta_{2}, \beta_{3}$ are the lineal coefficients, $\beta_{4}, \beta_{5}, \beta_{6}$ are the quadratic coefficients and $\beta_{7}, \beta_{8}, \beta_{9}$ are the interaction coefficients.

\section{RESULTS AND DISCUSSION}

\subsection{Conventional Pectinmethylesterase Extraction}

For the pectinmethylesterase activity, it was obtained a wide range of values between 0.01 (run 17) and 1.23 (run 3) $U / m g$ (d.b.). The lowest PME activity was obtained at the lowest $\mathrm{NaCl}$ concentration and at center point conditions for $\mathrm{pH}$ and time. On the other hand, highest PME activity was obtained at highest $\mathrm{pH}(\mathrm{pH}=8.0)$ and at center point conditions for $[\mathrm{NaCl}]$ and time.

Moreover, the ANOVA analysis showed that the significant effects $(\mathrm{p}<0.05)$ were linear terms of $\mathrm{NaCl}$ concentration and $\mathrm{pH}$ with a positive effect in both cases. On the other hand, the extracting time, at least in the range 20 - 120 minutes was not significant for the PME activity.

Experimental data were fitted to a second-order polynomial model for PME activity (Table 2).

Table 2. Second-order model equations for the response surface fitted to the experimental data points obtained in the conventional extraction as a function of $\mathrm{pH}(1), \mathrm{NaCl}$ concentration (2) and time (3).

\begin{tabular}{ccc}
\hline \multirow{2}{*}{ Coefficient } & Pectinmethylesterase activity & Protein content \\
\cline { 2 - 3 } & $\mathrm{U} / \mathrm{mg}$ (d.b.) & $\mathrm{mg}$.prot/mg (d.b.) \\
\hline Independent & & \\
$\beta_{0}$ & -1.46069 & -0.17714 \\
Linear & & \\
$\beta_{1}$ & 0.43937 & 0.16595 \\
$\beta_{2}$ & 1.39288 & 0.15610 \\
$\beta_{3}$ & -0.01002 & -0.00200 \\
Quadratic & & \\
$\beta_{4}$ & -0.01799 & -0.00899 \\
$\beta_{5}$ & -0.23622 & -0.02864 \\
$\beta_{6}$ & 0.00003 & -0.00001 \\
Crossproduct & & \\
$\beta_{7}$ & -0.11444 & -0.03726 \\
$\beta_{8}$ & 0.00058 & 0.00038 \\
$\beta_{9}$ & 0.00150 & 0.00096 \\
Regression & & 88.1 \\
$\mathrm{R}^{2}(\%)$ & 78.9 & \\
\hline
\end{tabular}


For the protein content results, the ANOVA analysis showed that linear $\mathrm{pH}$ term was highly significant with positive effect. Linear $[\mathrm{NaCl}]$ and crossproduct $\mathrm{pH}$ and $[\mathrm{NaCl}]$ terms, were also significant with a negative effect. As occurred with PME activity, time did not show significance. Protein content data were fitted to a secondorder polynomial model (Table 2).

Worst results in protein content $(0.001 \mathrm{mg} \cdot \mathrm{prot} / \mathrm{mg}$ (d.b.)) were obtained with run 3 what is in agreement with results obtained for the PME activity. The PME activity depends in some way on the protein content; hence, if experimental conditions in run 3 led to an extract with very limited protein content, the PME activity must be extremely low.

On the other hand highest protein content $(0.52$ $\mathrm{mg}$.prot/mg (d.b.)) was obtained at run 4 ( $\mathrm{pH}=7.0$, $[\mathrm{NaCl}]=0.5 \mathrm{M}$ and $\mathrm{t}=100 \mathrm{~min}$ ). These conditions differ from experimental conditions leading to highest PME activity. It was evaluated the relation between PME activity and protein content and no correlation was found. This fact proves that not all extracted proteins show catalytic function. Thus, in order to evaluate the catalytic power of the extracted protein it is possible to define a factor of PME effectiveness, $\eta_{\mathrm{PME}}$ (U/mg prot) (Eq.2).

$$
\eta_{\mathrm{PME}}=\frac{\mathrm{PME}_{\text {activity }}}{\text { Protein }_{\text {content }}}
$$

The ANOVA analysis was done for the $\eta_{\mathrm{PME}}$ too. It was found that the only significant effect was the $\mathrm{NaCl}$ concentration (positive effect) what was corroborated by the RSM plot (Figure 1).

The second-order polynomial equation for the $\eta_{\mathrm{PME}}$ (Eq.3) showed a $\mathrm{R}^{2}$ of $82.9 \%$.

$$
\begin{aligned}
& \eta_{\mathrm{PME}}=-3.1295+0.9515 X_{1}+3.6144 X_{2}-0.0253 X_{3} \\
& -0.0403 X_{1}^{2}-0.3442 X_{2}^{2}+0.0002 X_{3}^{2}-0.2876 X_{1} X_{2}(3) \\
& +0.0006 X_{1} X_{3}-0.0007 X_{2} X_{3}
\end{aligned}
$$

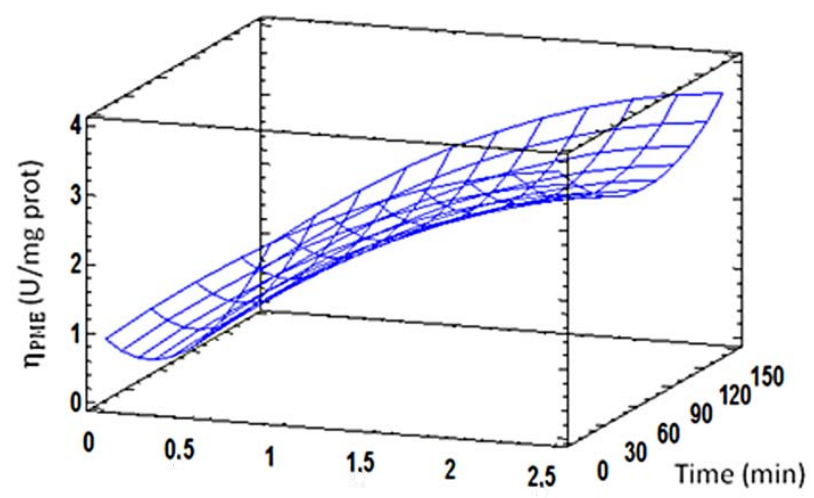

$\mathrm{NaCl}$ concentration (M)

Figure 1. Response surface plot for the PME effectiveness as a function of the $\mathrm{NaCl}$ concentration and time. The $\mathrm{pH}$ was fixed at 5.5 .
According to this ANOVA analysis, the experimental conditions that maximize the $\eta_{\mathrm{PME}}$ are: $\mathrm{pH}=5.9, \mathrm{NaCl}$ concentration $=2.5 \mathrm{M}$ and time $=20 \mathrm{~min}$, obtaining a maximum value of $\eta_{\mathrm{PME}}=3.33 \mathrm{U} / \mathrm{mg}$.prot.

\subsection{Ultrasound-Assisted Pectinmethylesterase Extraction}

In the ultrasound-assisted extraction, experiments were done at $\mathrm{pH}=5.5$ and $[\mathrm{NaCl}]=1.25 \mathrm{M}$ varying extraction time between 0 - $30 \mathrm{~min}$.

It was found that both PME activity and extracted protein showed a similar hyperbolic behavior with time course during extraction. Asymptotic values for PME activity and protein content were $0.85 \mathrm{U} / \mathrm{mg}$ (d.b.) and $0.41 \mathrm{mg} \cdot \mathrm{prot} / \mathrm{mg}$ (d.b.), respectively. The stabilization time was around $15 \mathrm{~min}$ in both cases.

Regarding the PME effectiveness evolution with the extraction time course (Figure 2), a hyperbolic trend was found with an asymptotic value of about $2.0 \mathrm{U} / \mathrm{mg}$.prot.

In order to compare conventional and ultrasound- assisted methods, second order model equations in Table 2 were used to find the expected values of PME activity and protein content at the stabilization conditions for the ultrasound-assisted extraction $(\mathrm{pH}=5.5 ; \mathrm{NaCl}=1.25 \mathrm{M}$; $\mathrm{t}=15 \mathrm{~min}$ ). The obtained values were $0.93 \mathrm{U} / \mathrm{mg}$ (d.b.) and $0.38 \mathrm{mg} \cdot \mathrm{prot} / \mathrm{mg}$ (d.b.) for PME activity and protein content, respectively.

As observed, expected PME activity for the conventional extraction $(0.93 \mathrm{U} / \mathrm{mg}$ (d.b.)) was higher than for the ultrasound-assisted method (0.85 U/mg (d.b.)). The contrary occurs with protein content, $0.38 \mathrm{mg} \cdot \mathrm{prot} / \mathrm{mg}$ (d.b.) with conventional extraction vs. $0.41 \mathrm{mg} \cdot \mathrm{prot} / \mathrm{mg}$ (d.b.).

Comparing the PME effectiveness for both extraction methods at the same extracting conditions $(\mathrm{pH}=5.5$; $\mathrm{NaCl}=1.25 \mathrm{M} ; \mathrm{t}=15 \mathrm{~min}$ ), the expected value for the conventional extraction reached $2.5 \mathrm{U} /$ mgrot. vs. the

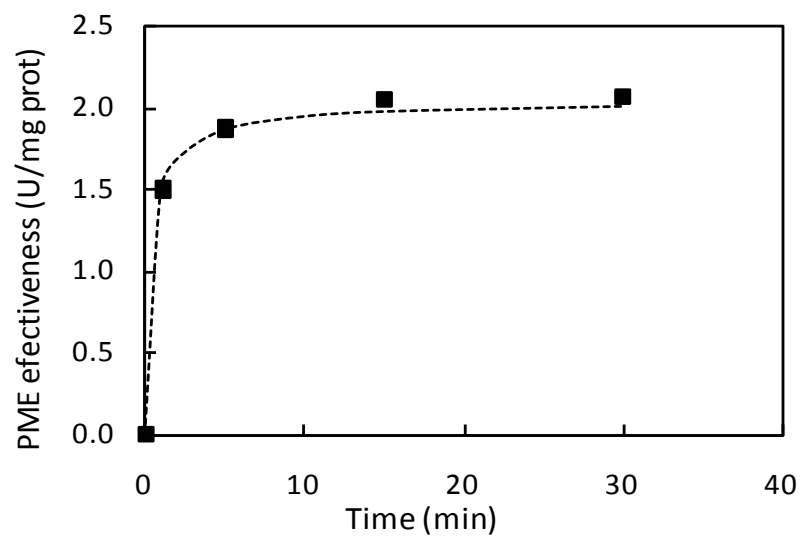

Figure 2. Evolution of the PME effectiveness as a function of the extraction time course. Experimental conditions: $\mathrm{pH}=5.5$ and $\mathrm{NaCl}$ concentration $=1.25 \mathrm{M}$. 
$2.0 \mathrm{U} / \mathrm{mg}$.prot. obtained for the ultrasound-assisted method. Hence, conventional extraction led to higher PME effectiveness in the extracts than the ultrasound-assisted extraction.

\section{CONCLUSIONS}

Variables studied (pH, $[\mathrm{NaCl}]$ and $\mathrm{t})$, had different effect on the PME activity, protein content and PME effectiveness $\left(\eta_{\mathrm{PME}}\right)$ in extracts for the conventional extraction: For PME activity, $[\mathrm{NaCl}]$ and $\mathrm{pH}$ were significant and had positive effect; for protein content, $\mathrm{pH}$ was highly significant with positive effect while, $[\mathrm{NaCl}]$ was less significant with a negative effect; for the $\eta_{\mathrm{PME}},[\mathrm{NaCl}]$ was found significant with positive effect. Model equations describing the PME activity, protein content and $\eta_{\text {PME }}$ of the extracts presented adequate regression coefficients. Experimental conditions that maximize $\eta_{\mathrm{PME}}$ were: $\mathrm{pH}=5.9,[\mathrm{NaCl}]=2.5 \mathrm{M}$ and time $=20 \mathrm{~min}$.

For ultrasound-assisted extraction, PME activity, protein content and $\eta_{\text {PME }}$ showed a similar hyperbolic behavior with time course during extraction. The stabilization time was around $15 \mathrm{~min}$ in both cases.

Comparing results for both extraction methods at the same extracting conditions $(\mathrm{pH}=5.5 ; \mathrm{NaCl}=1.25 \mathrm{M}$; $\mathrm{t}$ = $15 \mathrm{~min}$ ), conventional extraction led to slightly higher PME effectiveness than the ultrasound-assisted extraction, what is interesting in future industrial applications.

\section{ACKNOWLEDGEMENTS}

Authors acknowledge the Vicerrectorado de Investigación of the Universidad Politecnica de Valencia for the financial support (project 1965) from the call Proyectos de Nuevas Líneas de Investigación Multidisciplinares (PAID05-11).

\section{REFERENCES}

[1] Braddock, R.J. (1999) Handbook of citrus by-products and processing technology, John Wiley \& Sons, Inc., Hoboken.

[2] García, E., Gozálvez, J.M. and Lora, J. (2002) Use of reverse osmosis as a preconcentration system of waste leaching liquid from the citric juice production industry. Desalination, 148, 137-142. http://dx.doi.org/10.1016/S0011-9164(02)00667-7

[3] United States Department of Agriculture, USDA (2010) http://usda.mannlib.cornell.edu/MannUsda/viewSt atic-

Page.do?.url=http://usda.mannlib.cornell.edu/usda/ers/./8 9022/2006/index.html.

[4] Martín, M.A., Siles, J.A., Chica, A.F. and Martín, A. (2010) Biomethanization of orange peel waste. Bioresource Technology, 101, 8993-8999. http://dx.doi.org/10.1016/j.biortech.2010.06.133

[5] Bampidis, V.A. and Robinson, P.H. (2006). Citrus by- products as ruminant feeds: A review. Animal Feed Science and Technology, 128, 175-217.

http://dx.doi.org/10.1016/j.anifeedsci.2005.12.002

[6] Wing, J.M., Van Horn, H.H., Sklare, S.D. and Harris Jr., B. (1988) Effects of citrus molasses distillers solubles and molasses on rumen parameters and lactation. Journal of Dairy Science, 71, 414-420. http://dx.doi.org/10.3168/jds.S0022-0302(88)79571-5

[7] Garcia-Castello, E., Lora-Garcia, J., Garcia-Garrido, J. and Rodriguez-Lopez, A.D. (2006). Energetic comparison for leaching waste liquid from citric juice production using both reverse osmosis and multiple-effect evaporation. Desalination, 191, 178-185.

http://dx.doi.org/10.1016/j.desal.2005.09.012

[8] Garcia-Castello, E.M., Mayor, L., Chorques, S., Argüelles, A., Vidal-Brotóns, D. and Gras, M.L. (2011) Reverse osmosis concentration of press liquid from orange juice solid wastes: Flux decline mechanisms. Journal of Food Engineering, 106, 199-205. http://dx.doi.org/10.1016/j.jfoodeng.2011.05.005

[9] Garcia-Castello, E.M. and McCutcheon, J.R. (2011) Dewatering press liquor derived from orange production by forward osmosis. Journal of Membrane Science, 372, 97101. http://dx.doi.org/10.1016/j.memsci.2011.01.048

[10] Pagan, J., Ibarz, A., Llorca, M., Pagan, A. and BarbosaCanovas, G.V. (2001) Extraction and characterization of pectin from stored peach pomace. Food Research International, 34, 605-612. http://dx.doi.org/10.1016/S0963-9969(01)00078-3

[11] Cassano, A., Conidi, C. and Drioli, E. (2010) Physicochemical parameters of cactus pear (Opuntia ficus-indica) juice clarified by microfiltration and ultrafiltration processes. Desalination, 250, 1101-1104.

http://dx.doi.org/10.1016/j.desal.2009.09.117

[12] Liu, Y.Z., Dong, T., Lei, Y., Deng, X.-X. and Gu, Q.-Q. (2011) Isolation of polygalacturonase gene from Citrus sinensis fruit and its expression relative to fruit mastication trait, fruit development, and calcium and boron treatments. Plant Molecular Biology Reporter, 29, 51-59. http://dx.doi.org/10.1007/s11105-010-0206-0

[13] Arbaisah, S.M., Asbi, B.A., Junainah, A.H. and Jamilah, B. (1996) Determination of optimum conditions for pectinesterase extraction from soursop fruit (Anona muricata) using response surface methodology. Food Chemistry, 55, 289-292.

http://dx.doi.org/10.1016/0308-8146(95)00105-0

[14] Contreras-Esquivel, J.C., Correa-Robles, C., Aguilar, C.N., Rodríguez, J., Romero, J. and Hours, R. (1999) Pectinesterase extraction from Mexican lime (Citrus aurantifolia Swingle) and prickly pear (Opuntia ficus indica L.) peels. Food Chemistry, 65, 153-156. http://dx.doi.org/10.1016/S0308-8146(98)00012-0

[15] Hou, W.N., Jeong, Y., Walker, B.L., Wei, C.I. and Marshall, M.R. (1997) Isolation and characterization of pectinesterase from Valencia orange. Journal of Food Biochemistry, 21, 309-333. http://dx.doi.org/10.1111/j.1745-4514.1997.tb00211.x

[16] Vivar-Vera, M.A., Salazar-Montoya, J.A., Calva-Calva, G. and Ramos-Ramirez, E.G. (2007). Extraction, termal sta- 
bility and kinetc behavior of pectinmethylesterase from hawthorn (Crataegus pubescens) fruit. LWT-Food Science and Technology, 40, 278-284.

http://dx.doi.org/10.1016/j.lwt.2005.10.005

[17] Zhou, H.-W., Ben-Arie, R. and Lurie, S. (2000) Pectin esterase, polygalacturonase and gel formation in peach pectin fractions. Phytochemistry, 55, 191-195.

http://dx.doi.org/10.1016/S0031-9422(00)00271-5
[18] Kertesz, Z.I. (1955) Pectic enzymes. Methods in Enzimology, 1, 158-166.

[19] Bradford, M.M. (1976) A rapid and sensitive method for quantitation of microgram quantities of protein utilizing the principle of protein-dye binding. Analytical Biochemistry, 72, 248-254.

http://dx.doi.org/10.1016/0003-2697(76)90527-3 